\title{
ANALISIS KEMAMPUAN KOMUNIKASI MATEMATIS SISWA SMP DI TINJAU
}

\section{DARI SELF-CONCEPT}

\author{
Melly Susanti ${ }^{1}$, Hana Ismatillah Kurnia ${ }^{2}$, Puji Nurfauziah ${ }^{3}$, Heris Hendriana ${ }^{4}$ \\ 1,2,3,4 IKIP Siliwangi \\ ${ }^{1}$ mellysusanti994@gmail.com ${ }^{2}$ hanaismatillahkurnia1503966@gmail.com \\ 33puji_fauziahahmad@yahoo.com ${ }^{4}$ hendriana@stkipsiliwangi.ac.id
}

\begin{abstract}
This study aims to describe the mathematical communication abilities in terms of selft concept of studens of class VIII junior high school 10 Cimahi. This research method is included in this type of research descriptive research is qualitative, describes approach the errors of students in answering questions mathematical communication seen from selft concept. The research in the test to 22 students in the sample in this study is 9 students. The determination of the sampling is done by taking the 3 students that have high self concept, 3 students who have self concept, and 3 student have low self concept. The result of data analysis showed the ability of mathematical communication for students who have hgh self concept that is 2 students showed the test of mathematical communication ability enough and 1 student low. Mathematical communication skills for students who have a moderate self concept that is 2 students showed good mathematical cominication ability test and 1 low students. The ability of mathematical communication for students who have a low selft concept that is 2 student showed less mathematical ability test and 1 students enough.
\end{abstract}

Keywords: Mathematical Communication, Self-Concept

\section{ABSTRAK}

Penelitian ini bertujuan untuk mendeskripsikan kemampuan komunikasi matematis yang ditinjau dari self concept siswa kelas VIII SMP Negri 10 Cimahi. Metode ini berjenis penelitian deskriptif dengan pendekan kualitatif, penelitian ini mendeskripsikan kesalahan siswa dalam menjawab soal-soal komunikasi matematis yang dilihat dari self-concept. penelitian ini di ujikan ke pada 22 siswa yang menjadi Sampelnya adalah 9 siswa. sampel yang di tentukan dilakukan dengan mengambil 3 siswa yang memiliki self concept tinggi, 3 siswa yang memiliki self concept sedang, dan 3 siswa yang memiliki self concept rendah. Hasil analisis data menunjukan kemampuan komuikasi matematis untuk siswa yang memiliki self concept tinggi yaitu 2 siswa menunjukan tes kemampuan komunikasi matematisnya cukup dan 1 siswa yang rendah. kemampuan komuikasi matematis untuk siswa yang memiliki self concept sedang yaitu 2 siswa menunjukan tes kemampuan komunikasi matematisnya baik dan 1 siswa yang rendah. kemampuan komuikasi matematis untuk siswa yang memiliki self concept rendah yaitu 2 siswa menunjukan tes kemampuan komunikasi matematisnya kurang dan 1 siswa yang cukup.

Kata kunci : Kemampuan Komunikasi Matematis, self concept

How to cite: Susanti, M., Kurnia, H. I., Nurfauziah, F., \& Hendriana, H. (2018). Analisis Kemampuan Komunikasi Matematis Siswa SMP di Tinjau dari Self-Concept. JPMI - Jurnal Pembelajaran Matematika Inovatif, 1 (5), 923-932

\section{PENDAHULUAN}

Tujuan pembelajaran matematika adalah agar siswa dapat memiliki kemampuan mengkomunikasikan gagasan dan ide dengan simbol, tabel, grafik, diagram atau media untuk memperjelas suatu permasalahan. Sumarmo (Yonandi, 2011) menyatakan bahwa komunikasi 
matematis merupakan keterampilan menyampaikan ide atau gagasan dalam bahasa sehari-hari atau dalam bahasa simbol matematika.

Hulukati (Minarti \& Nurfauziah, 2016) menyatakan bahwa kemampuan komunikasi matematis merupakan syarat untuk memecahkan masalah, artinya jika siswa tidak dapat berkomunikasi dengan baik memaknai permasalahan maupun konsep matematika maka ia tidak dapat menyelesaikan masalah tersebut dengan baik. Kemampuan komunikasi mempunyai peranan penting sebagai representasi kemampuan pemahaman konsep, masalah sehari-hari dan aplikasi konsep matematika dalam disiplin ilmu lain (Hidayat \& Sumarmo, 2013).

Kenyataan dilapangan saat ini menunjukkan kondisi yang berbeda dengan situasi yang diharapkan. Yang terjadi disekolah, menguasaan matematika siswa SMP masih rendah, komunikasi matematik siswa untuk belajar matematika masih kurang dan self-consept siswa sangat rendah, sehingga hasil dari pembelajarannya kurang bermakna. Sejalan dengan penelitian Sumarmo yang mengemukakann bahwa keadaan skor kemampuan siswa dalam pemahaman dan komunikasi matematis siswa masih rendah. Siswa masih banyak mengalami kesukaran dalam pemahaman resional dan berfikir derajat kedua, artinya siswa mengalami kesukaran dalam tes pemahaman dan komunikasi (Dini, 2018).

Kemampuan komunikasi matematis dan self-consept siswa yang masih rendah, terjadi di SMP Negeri 10 Cimahi. Berdasarkan hasil wawancara dan pengisian angket oleh guru dan siswa, diperoleh informasi bahwa siswa sering mengalami kesulitan ketika dihadapkan dengan soal kontekstual tanpa disertai dengan ilustrasi gambar. Rahman (2012) menyatakan bahwa selain kemampuan komunikasi matematis, terdapat aspek psikologi yang memberikan kontribusi terhadap keberhasilan seseorang dalam menyelesaikan permasalahan matematika dengan baik.

Dalam mengembangan kemampuan matematika khususnya kemampuan komunikasi, salah satu aspek psikologi yang dibutuhkan adalah self-consept terhadap matematika. Douglas (2000) mengemukakan bahwa self-consept terhadap matematika adalah persepsi atau pandangan seseorang mengenai kemampuannya untuk belajar matematika. Self-concept matematis adalah keyakinan, perasaan atau sikap seseorang mengenai kemampuannya dalam memahami atau melakukan sesuatu dalam situasi yang melibatkan matematika (Pamungkas, 2012). Tujuan penulisan artikel ini diantaranya adalah bagi siswa, diharapkan siswa dapat menggali dan mengembangkan kepercayaan diri dan kemampuan dirinya, dan bagi guru untuk mengetahui pengaruhnya kemampuan komunikasi terhadap self-concept.

Berdasarkan hal tersebut, perlu dilakukan penelitian yang menjadi urgensi permasalahan tentang seberapa besar kemampuan komunikasi matematis dipengaruhi oleh self-concept siswa.

\section{METODE}

Metode penelitian ini adalah jenis penelitian deskriptif dengan pendekan kualitatif, penelitian ini mendeskripsikan kesalahan siswa dalam menjawab soal-soal komunikasi matematis yang dilihat dari self-concept. Data penelitian ini yaitu jawaban tertulis dan lisan yang diperoleh dari tes tertulis dan wawancara. Subjek penelitian ini yaitu siswa kelas VIII SMP Negri 10 Cimahi dengan kemampuan tinggi, sedang, dan rendah. Instrumen tes berupa tes tertulis yang 
memuat enam butir soal disertai dengan wawancara dan self-consept berupa angket yang berupa pernyataan positif dan negatif.

Kegiatan awal yang dilakukan oleh peneliti ini adalah menguji cobakan instrumen komunikasi matematis berdasarkan indikator yang terdiri dari 6 soal. Instrumen yang telah dibuat kemudian diujikan kepada siswa SMP kelas VIII untuk pengambilan data. Selain menggunakan soal instrumen peneliti juga menyusun angket self-concept, dalam hal ini peneliti menggunakan angket dari Sumarmo (2017), kemudian peneliti memodifikasi angket tersebut.

Arikunto (2008) menyatakan hasil angket self concept di analisis untuk mengetahui tingkatan self concept siswa yaitu sellf concept tinggi 81 - 100\%, self concept sedang $51-80 \%$, self concept rendah $30-50 \%$, dan self concept sangat rendah $0-29 \%$. Tes kemampuan komunikasi akan dianalisis untuk mengetahui hasil kemampuan komunikasi untuk tiap-tiap kategori self concept (tinggi, sedang, dan rendah). Sedangkan wawancara dilakukan untuk mengetahui kemampuan komunikasi siswa secara mendalam dan bagaimana proses siswa saat menyelesaikan soal komunikasi.

Tahapan penelitian ini, adalah:

(1) Menyiapkan hasil instrumen penelitian berupa kisi-kisi, soal kemampuan Komunikasi matematis, hasil jawaban dari, kisi-kis angket self concept ;

(2) Melakukan validasi, rehalibitas,daya pembeda, indeks kesukaran terhadap instrumen penelitian;

(3) Melakukan revisi instrumen penelitian berdasarkan hasil validasi;

(4) Melakukan uji coba soal tes di kelas VIII SMP Negri 10 Cimahi ;

(5) Menganalisis data hasil uji coba instrumen komunikasi;

(6) Memberikan angket self concept kepada siswa kelas VIII SMP Negri 10 Cimahi ;

(7) Menganalisis angket self concept;

(8) Memberikan skor dan menganalisis jawaban siswa;

(9) Melakukan wawancara kepada siswa dari hasil angket dan soal tes;

(10) Mendeskripsikan hasil penelitian;

(11) Menarik kesimpulan;

\section{HASIL DAN PEMBAHASAN}

Dari hasil penelitian yang telah dilakukan dikelas VIII SMP Negri 10 Cimahi, akan menghasilkan data dari hasil jawaban siswa pada angket self concept, tes kemampuan komunikasi dan hasil dari wawancara siswa. Dibawah ini adalah hasil dan deskripsinya sebagai berikut:

\section{Hasil}

\section{Deskripsi Hasil dan Analisis Angket Self Concept Siswa}

Hasil data yang telah dikumpulakan dari penyebaran angket terhadap 22 siswa di Kelas VII, data yang di dapat dari keseluruhan dapat melihat tingkatan self concept (tinggi, sedang, dan rendah). Hasil tingkatan self concept diperoleh dengan skala Likert, data keseluruhannya akan disajikan dalam tabel 1 di bawah ini. 
Tabel 1. Data Hasil Angket Self Concept Siswa

\begin{tabular}{ccc}
\hline $\begin{array}{l}\text { Tingkatan } \\
\text { Self Concept }\end{array}$ & Kode siswa & \multicolumn{2}{c}{$\begin{array}{l}\text { Jumlah } \\
\text { Siswa }\end{array}$} \\
\hline Tinggi & $\mathrm{s}-7, \mathrm{~s}-11, \mathrm{~s}-13, \mathrm{~s}-15$, & 4 \\
Sedang & $\mathrm{s}-1, \mathrm{~s}-2, \mathrm{~s}-4, \mathrm{~s}-5, \mathrm{~s}-6, \mathrm{~s}-9, \mathrm{~s}-10, \mathrm{~s}-14, \mathrm{~s}-16, \mathrm{~s}-17, \mathrm{~s}-$ & 14 \\
& $18, \mathrm{~s}-19, \mathrm{~s}, 20, \mathrm{~s}-22$ & \\
& $\mathrm{~s}-3, \mathrm{~s}-8, \mathrm{~s}-12, \mathrm{~s}-21$ & 4 \\
\hline
\end{tabular}

Dari hasil Tabel 1 dapat dilihat ketiga tingkatan self concept yaitu self concept tinggi, self concept sedang, dan self concept rendah diperoleh siswa kelas VIII SMP Negri 10 Cimahi yang memiliki self concept tinggi sebanyak yaitu 4 siswa, siswa yang memiliki self concept sedang sebanyak 14 siswa dan siswa yang memiliki self concept rendah sebanyak 4 siswa.

\section{Deskripsi Hasil dan Analisis Jawaban Siswa yang Memiliki Self Concept Sedang}

Tingkatan self concept dipilih 3 siswa yang akan mewakili tiap kategori tingkatan . Data yang terkumpul dari hasil tes kemampuan kemampuan komunikasi, bahwa kemampuan komunikasi dari ketiga siswa yang memiliki self concept sedang berbeda-beda.Hasil kemampuan komunikasi siswa yang tingkatan self conceptnya tinggi disajikan dalam tabel 2 di bawah ini.

Tabel 2. Data Tes Kemampuan Komunikasi pada Siswa yang Memiliki Self Concept sedang

\begin{tabular}{llll}
\hline $\begin{array}{l}\text { Tingkatan } \\
\text { Self } \text { Concept }\end{array}$ & Kode siswa & $\begin{array}{l}\text { Nilai } \\
\text { siswa }\end{array}$ & $\begin{array}{l}\text { Presentase } \\
\text { Nilai siswa }\end{array}$ \\
\hline Sedang & s-7 & 16 & $77 \%$ \\
& s-11 & 12 & $70 \%$ \\
& s-13, & 17 & $71 \%$ \\
\hline
\end{tabular}

Data hasil tabel 2 dapat dilihat bahwa kemapuan komunikasi siswa yang ditinjau dari selfconcept sedang, hasil kemampuan komunikasinya juga baik. Hal ini dapat dilihat dari hasil tes kemampuan komunikasi, siswa S-7 memperoleh nilai 16 dan hasil presentasinya 77\%, siswa S-11 memperoleh nilai 12 dan hasil presentasinya 70\%, dan S-13 memperoleh nilai 17 dan hasil presentasenya 71\% sehingga interpretasinya dalam kategori sedang.

\section{Deskripsi Hasil dan Analisis Jawaban Siswa yang Memiliki Self Concept Tinggi}

Tingkatan self concept dipilih 3 siswa yang akan mewakili tiap tingkatan. Data yang terkumpul dari hasil tes kemampuan komunikasi matematis, bahwa kemampuan komunikasi matematis dari ketiga siswa yang tingkatan self concept Tinggi hasilnya tidak sama. Hasil kemampuan komunikasi siswa yang tingkatan self conceptnya sedang disajikan dalam tabel 3 di bawah ini. 
Tabel 3. Data Tes Kemampuan Komunikas pada Siswa yang Memiliki Self Concept tinggi

\begin{tabular}{ccrc}
\hline $\begin{array}{c}\text { Tingkatan } \\
\text { Self Concept }\end{array}$ & Kode siswa & $\begin{array}{r}\text { Nilai } \\
\text { siswa }\end{array}$ & $\begin{array}{l}\text { Presentase } \\
\text { Nilai siswa }\end{array}$ \\
\hline sedang & S-1 & 19 & $80,16 \%$ \\
& S-2 & 23 & $85 \%$ \\
& S-4 & 19 & $80,16 \%$ \\
\hline
\end{tabular}

Data hasil Tabel 3 dapat dilihat bahwa kemapuan komunikasi siswa yang ditinjau dari selfconcept tinggi, hasil kemampuan komunikasinya juga sangat baik. Hal ini dapat dilihat dari hasil tes kemampuan komunikasi, siswa S-1 memperoleh nilai 19 dan hasil presentasinya $80,16 \%$, siswa S-2 memperoleh nilai 23 dan hasil presentasinya 85\%, dan S-4 memperoleh nilai 19 dan hasil presentasenya $80,16 \%$ sehingga interpretasinya dalam kategori tinggi.

\section{Deskripsi Hasil dan Analisis Jawaban Siswa yang Memiliki Self Concept Rendah}

Tingkatan self concept dipilih 3 siswa yang akan mewakili tiap tingkatan. Data yang terkumpul dari hasil tes kemampuan komunikasi matematis, bahwa kemampuan komunikasi matematis ketiga siswa yang tingkatan self concept rendah hasilnya berbeda-beda. Hasil kemampuan komunikasi siswa yang tingkatannya self concept rendah akan disajikan dalam tabel 3 di bawah ini.

Tabel 4. Data Tes Kemampuan Komunikasi pada Siswa yang Memiliki Self Concept rendah

\begin{tabular}{llll}
\hline $\begin{array}{l}\text { Tingkatan } \\
\text { Self Concept }\end{array}$ & Kode siswa & $\begin{array}{l}\text { Nilai } \\
\text { siswa }\end{array}$ & $\begin{array}{l}\text { Presentase } \\
\text { Nilai siswa }\end{array}$ \\
\hline rendah & S-3 & 11 & 45,83 \\
& S-12 & 5 & 20,83 \\
& S-18 & 14 & 58,33
\end{tabular}

Data hasil Tabel 4 dapat dilihat bahwa kemapuan komunikasi siswa yang ditinjau dari selfconcept rendah, hasil kemampuan komunikasinya juga rendah. Hal ini dapat dilihat dari hasil tes kemampuan komunikasi, siswa S-3 memperoleh nilai 11 dan hasil presentasinya 45,83\%, siswa S-12 memperoleh nilai 5 dan hasil presentasinya 20,83\%, dan S-18 memperoleh nilai 14 dan hasil presentasenya 58,33\% sehingga interpretasinya dalam kategori rendah.

Berdasarkan deskripsi tes kemampuan komunikasi dari masing-masing kategori self-concept siswa diperoleh bahwa masing-masing kategori self-concepnya mempunyai hasil kemampuan komunikasi yang hasilnya berbeda-beda. Ini semua dapat dilihat dari tabel 5 dibawah ini. 
Tabel 5. Kemampuan Komunikasi Matematis Siswa Berdasarkan Self Concept Siswa

\begin{tabular}{llccc}
\hline & \multicolumn{3}{c}{ Tingkatan } & kode \\
\hline Self & siswa & \multicolumn{2}{c}{ kemampuan komunikasi matematis } & \\
\cline { 3 - 5 } Concept & & baik & sedang & rendah \\
\hline Tinggi & S-1 & $\sqrt{ }$ & & \\
& S-2 & $\sqrt{ }$ & $\sqrt{ }$ & \\
& S-4 & $\sqrt{ }$ & $\sqrt{ }$ & \\
Sedang & S-7 & & $\sqrt{ }$ & \\
& S-11 & & & $\sqrt{ }$ \\
& S-13 & & & $\sqrt{ }$ \\
Rendah & S-3 & & & \\
& S-12 & & & \\
& S-18 & & & \\
\hline
\end{tabular}

\section{Pembahasan}

\section{Hasil Angket dan Jawaban Siswa}

Rini dalam (Murmanto, 2007) menyatakan bahwa konsep diri (self concept) terbentuk melalui proses belajar sejak maa pertumbuhan seseorang individu dariia kecil hingga dewasa. Lingkungan serta pengalaman individu tersebut dalam berinteraksi dengan individu lain memberikan pengaruh yang signifikan terhadap self concept yang terbentuk. Pendapat tersebut sejalan dengan yang dikemukakan oleh (Nirmalawati, 2011), bahwa terbentuknya konsep diri karena adanya pengalaman diri serta adanya interaksi dengan orang-orang di sekitarnya dan pembentukannya melalui beberapa bagian yang setiap bagiannya harus seimbang agar tercipta individu dengan konsep diri yang baik, sehingga konsep diri yang baik dalam waktu yang relatif lama dan berkembang melalui tahapan tertentu. (Murmanto, 2007) mengungkapkan bahwa untuk membentuk konsep diri siswa yang baik perlu dipersiapkan sebuah kurikulum yang meliputi aspek kognitif, psikomotorik dan afektif.

Hasil dari analisis penelitian ini yang diperoleh tentang kemampuan komunikasi matematis yang di tinjau dari self concept siswa, sebelumnya telah diketahui bahwa dari hasil angket terlihat siswa dengan tingkatan self concept yang berbeda. Terdapat tingkatan 4 siswa dengan kategori self concept tinggi, 14 orang siswa memiliki self concept sedang, dan 4 orang siswa yang tingkatan self conceptnya rendah. Berdasarkan hasil angket, menunjukkan bahwa self concept yang dimiliki siswa tersebut menyertainya dalam menyelesaikan masalah pada tes soal kemampuan komunikasi matematis. Hal ini dapat dilihat dari Siswa (S-1), (S-2) dan (S4) yang tingkatan self conceptnya tinggi pada saat diberikan tes soal komunkasi matematika, sudah mampu menyatakan peristiwa sehari - hari dalam bahasa atau simbol matematika, tetapi pada langkah terakhir yaitu memeriksa kembali jawaban dan penarikan kesimpulan sudah mampu menyatakan peristiwa sehari-hari dalam bahasa atau sismbol matematika, masih ada sedikit kesalahan ketika menyelesaikan soal tersebut jawabannya kurang tepat. Penelitian ini sejalan dengan (Maulani, D., Suyono., Noornia, 2017) di sisi lain, self-concept siswa juga memberikan kontribusi terhadap kemampuan komunikasi matematis karena dalam realisasi beberapa indikator komunikasi matematis juga berkaitan dengan pemahaman siswa akan dirinya (konsep diri). 
Siswa (S-7), (S-11), (S-13) yang memiliki self concept sedang pada saat diberikan tes soal komunikasi matematis, siswa (S-7), (S-13), dan (S-11) sudah bisa menyatakan peristiwa sehari-hari dalam bahasa atau simbol matematika. Siswa (S-7) kemudian dapat melakukan perhitungan dengan benar, pada langkah terakhir siswa (S-13) tidak menulis hasil kesimpulan, sedangkan (S-7) belum bisa menyimpulkan sesuai dengan permasalahan awal secara lengkap dan tidak melakukan pemeriksaan kembali jawabannya. Ini sejalan dengan penelitian yang dilakukan oleh Wijaya, (2017) menyatakan bahwa persentase rata-rata kemampuan siswa dalam menyatakan peristiwa sehari-hari dalam bahasa atau simbol matematika. Hal ini berarti hampir seluruh siswa mampu menyatakan peristiwa sehari-hari dalam bahasa atau simbol matematika.

Penelitian yang dilakukan oleh (Widiarti, 2017) bahwa konsep diri yang senderung rendah adalah konsep diri etik, moral, sosial dan personal maka digunakan pendekatan bagi pendamping dari sisi komunikasi. Ini sejalan dengan penelitian yang kami lakukan bahwa siswa (S-3), (S-12) dan (S-18) yang tingkatan self conceptnya rendah, pada saat diberikan tes soal komunikasi matematis , siswa (S-3), (S-12) belum bisa ketika menyelesaikan, membuat konjektur, menyusun argumen merumuskan definisi dan generalisasi. Sedangkan siswa (S-3) dan (S-12) dan (S-18) kurang mampu dalam menyelesaikan penyelesaian soal, pelaksanaan perhitungan, dan penarikan kesimpulan dengan baik.

\section{Hasil Wawancara Siswa}

Untuk mempertegas hasil angket dan tes yang dikerjakan oleh siswa-siswa tersebut, sebagai kegiatan tindak lanjut maka peneliti melakukan wawancara kepada 9 siswa tersebut. Berdasarkan hasil wawancara dengan siswa (S-7), siswa (S-7) mampu menyelesaikan soal dengan cukup walaupun masih ada kesalahan . hasil dari pembahasan soal no 1 adalah salah satunya menyatakan peristiwa dalam sehari-hari bahasa satu simbol matematika; lalu membuat model situasi atau dengan menggunakan metode lisan, tertulis, konkrit dan grafik; kemudian dengan menghubungkan benda-benda nyata, gambar dan diagram ke dalam ide matematika; dan yang terakhir membuat konjektur, menyusun argumen merumuskan definisi dan generalisasi, siswa (S-7) melakukannya dengan cukup baik.

Wawancara selanjutnya dilakukan dengan siswa (S-11), berdasarkan hasil wawancara siswa (S-11) belum mampu menyelesaikan soal dengan benar. Dari soal-soal pertama, yaitu menyatakan peristiwa sehari-hari dalam bahasa satu simbol matematika, selanjutnya membuat model situasi atau persoalan menggunakan metode lisan, tertulis, konkrit dan grafik, menghubungkan benda-benda nyata, gambar dan diagram ke dalam ide matematika, membuat konjektur, menyusun argumen merumuskan definisi dan generalisasi, siswa (S-11) tidak melakukannyadengan baik. Tetapi tidak melakukan pemeriksaan kembali argument dari tiap-tiap langkah penyelesaian.

Wawancara kemudian dilakukan dengan siswa (S-13), berdasarkan hasil wawancara siswa (S13) cukup mampu memecahkan masalah yang terdapat didalam soal. Hasil dari analisis soal dengan kategori cukup, adalah yang pertama menyatakan peristiwa sehari-hari dalam bahasa satu simbol matematika; lalu yang kedua yaitu dengan membuat model situasi ataupun persoalan menggunakan metode lisan, tertulis, konkrit dan grafik; selanjutnya yang ketiga adalah dengan menghubungkan benda-benda nyata, lalu gambar dan diagram ke dalam ide matematika; kemudian yang terakhir yaitu membuat konjektur, menyusun argumen merumuskan definisi dan generalisasi, dan hasil pembahasan dari siswa (S-11) tidak melakukannya cukup baik walaupun masih ada soal yang keliru. 
Wawancara selanjutnya dengan siswa (S-2), berdasarkan hasil wawancara siswa tidak mampu menyelesikan soal komunikasi matematis tetapi tidak secara keseluruhan. Pada langkah pertama, yaitu menyatakan peristiwa sehari-hari dalam bahasa satu simbol matematika, siswa (S-2) belum bisa menyimpulkan sesuai dengan permasalahan awal secara lengkap dan tidak melakukan pemeriksaan kembali jawabannya. Tetapi

pada langkah selanjutnya siswa (S-2) mampu membuat model situasi atau persoalan menggunakan metode lisan, tertulis, konkrit dan grafik walaupun tidak menyelesaikan soal tersebut dengan benar. Sedangkan ketika wawancara pada siswa (S-1) dan (S-4) mampu menyelesaiakn hasil komunikasi matematis dengan baik walaupun masih ada kesimpulan penyelesaian tidak dituliskan.

Wawancara kemudian dilakukan dengan siswa (S-3), (S-12), dan (S-18). Berdasarkan hasil wawncara dengan ketiga siswa tersebut, siswa (S-3), (S-12) kurang mampu dalam menyelesaikan soal. Hasil dari pembahasan soal-soal pertama, adalah dengan menyatakan peristiwa sehari-hari dalam bahasa satu simbol matematika; selanjutnya yang kedua yaitu dengan membuat model situasi ataupun persoalan menggunakan metode lisan, tertulis, konkrit ataupun grafik; dan yang ketiga dengan menghubungkan benda-benda nyata, gambar maupun diagram ke dalam ide matematika; kemudian hasil yang terakhir dengan membuat konjektur, menyusun argumen merumuskan definisi maupun generalisasi. Mereka kurang mampu dalam menyelesaikan soal komunikasi matematis, sedangkan siswa (S-18) mampu menyelesaikan komnikasi matematis dengan cukup baik walau siswa S-18 tidak menyelesaikan jawaban dengan selesai.

\section{KESIMPULAN DAN SARAN}

Berdasarkan hasil penelitian dan pembahasan secara umum dapat disimpulkan bahwa kemampuan komunikasi dikaji dari self concept siswa adalah adanya perbedaan kemampuan komunikasi matematis untuk tiap tingkatan self concept. Secara rinci dapat disimpulkan sebagai berikut:

1) Kemampuan komunikasi matematis pada siswa yang memiliki self concept tinggi adalah sangat baik. Siswa yang memiliki self concept tinggi dapat memenuhi semua indikator dalam kemampuan komunikasi , yaitu mampu menyatakan peristiwa sehari - hari dalam bahasa atau simbol matematika.

2) Kemampuan komunikasi matematis pada siswa yang memiliki self concept sedang adalah sedang. Siswa yang memiliki self concept sedang dapat memenuhi tiga indikator menyatakan peristiwa shari - hari dalam bahasa atau simbol matematika, dan tidak memeriksa kembali hasil jawaban.

3) Kemampuan komunikasi matematis pada siswa yang memiliki self concept rendah adalah rendah . Siswa yang memiliki self concept rendah dapat memenuhi indikator menyelesaikan, membuat konjektur, menyusun argumen merumuskan definisi dan generalisasi.

Dengan menyadari masih adanya kelemahan-kelemahan pada penelitian ini sehingga disarankan kepada mahasiswa/i yang lain untuk mengadakan penelitian lebih lanjut guna memperoleh hasil yang lebih baik dengan memperkecil kelemahan-kelemahan yang ada di dalam penelitian ini. Adapun saran yang dapat disampaikan, yaitu: (1) Membuat skor tes kemampuan komunikasi matematis mungkin terhadap kemungkinan-kemungkinan jawaban siswa; (2) Untuk para guru, sebaiknya memperhatikan self concept yang ada dalam diri siswa, karena self concept salah satu faktor yang mempengaruhi dalam keberhasilan siswa; (3) 
Untuk para guru, sebaiknya lebih banyak menggunakan soal kemampuan komunikasi matematis yang bisa membuat siswa mengembangkan kemampuan komunikasi matematis dan membiasakan siswa untuk menyelesaikan soal yang yang tidak rutin.

\section{UCAPAN TERIMA KASIH}

Penulis mengucapkan terimakasih kepada pihak yang terkait demi kelangsungan penelitian ini. Termasuk didalamnya Dr. H. Heris Hendriana, M.Pd. dan Puji Nurfauziah, M.Pd. karena dukungan dan bimbingannya dalam menyelesaikan penelitian ini. Tak lupa kepada pihak SMP yang dijadikan tempat berlangsungnya penelitian.

\section{DAFTAR PUSTAKA}

Arikunto, S. (2008). Penelitian Tindakan Kelas. Retrieved from Jakarta Bumi Aksara.

Dini, M. (2018). Pengaruh Self Confidence Terhadap Kemampuan Pemahman Matematik Siswa SMP. Jurnal Silogisme, 1(3), 1-7.

Douglas, A. (2000). Math Anxiety, Math Self-Concept, and Performance in Math. Canada: Faculty of Education Lakehead Univercity.

Hidayat, W., \& Sumarmo, U. (2013). Kemampuan Komunikasi dan Berpikir Logis Matematika serta Kemandirian Belajar. dalam Jurnal Delta-fi, 2(1).

Maulani, D., Suyono., Noornia, A. (2017). Pengaruh Penerapan Model Reciprocal Teaching terhadap Kemampuan Komunikasi Matematis ditijau dari Self-concept Siswa di SMAN Kecamatan Tambun Selatan Bekasi. Jurnal Penelitian Dan Pembelajaran Matematika, 10(02), 14-24.

Minarti, E. D., \& Nurfauziah, P. (2016). Pendekatan Kontruktivisme dengan Model Pembelajaran Generatif Guna Meningkatkan Kemampuan Komunikasi dan Koneksi Matematis serta Self Efficacy Mahasiswa Calon Guru di Kota Cimahi. Jurnal Ilmiah P2m STKIP Siliwangi Bandung, 03(02), 68-83.

Murmanto., M. D. (2007). Pembentukan Konsep Diri Siswa melalui Pembelajaran Partisipatif. Jurnal Pendidikan Penabur., 04(08), 66-74.

Nirmalawati. (2011). Pembentukan Konsep Diri pada Siswa Pendidikan Dasar dalam Memahami Mitigasi Bencana. Jurnal SMARTek, 09(01), 61-69.

Pamungkas. (2012). Pembelajaran eksplorasi untuk mengembangkan kemampuan berpikir logis dan self concept matematis mahasiswa sekolah menengah pertama.

Rahman. (2012). Hubungan antara Self-concept Terhadap Matematika dengan Kemampuan Berpikir Matematik Siswa. Jurnal Ilmiah Program Studi Matematika STKIP Siliwangi Bandung, 01(01).

Sumarmo, D. (2017). Hard Skills dan Soft Skills. Bandung: Refika Aditama.

Widiarti, W. P. (2017). Konsep Diri (Self Concept) dan Komunkasi Interpersonal dalam Pendampingan pada Siswa SMP Se Kota Yogyakarta, 47(1), 135-148.

Wijaya, T. T., Afrilianto, M. (2017). Kemampuan Komunikasi Siswa SMK. Jurnal JPMI, 1(1), 53-60.

Yonandi. (2011). Meningkatkan Kemampuan Komunikasi Matematik Siswa Sekolah Menengah Atas Melalui Pembelajaran Kontekstual Berbantuan Komputer. Jurnal Pendidikan Matematika, 2(2), 133-146. 
932 Susanti, Kurnia, Nurfauziah, \& Hendriana, Analisis Kemampuan Komunikasi.......... 